\title{
Information and Communication Technology (ICT) Benefits as Learning Media in SD Negeri Berkat OKI District
}

\author{
Karmila $^{1 *}$, Bukman Lian², Syaiful Eddy ${ }^{2}$ \\ ${ }^{1}$ SD Negeri 4 Berkat, OKI District, South of Sumatra, Indonesia \\ ${ }^{2}$ Universitas PGRI Palembang, Indonesia \\ *Corresponding author. Email: karmila11101992@gmail.com
}

\begin{abstract}
The goal of this study is to determine the benefits of information and communication technology or ICT, in short, as a means of learning. ICT is a medium or instrument used to balance the rapid development of technology. The approach used in this study is qualitative methods with data collection techniques with triangulation (combined). By using ICT that is effective and productive, attractive, optimal and stimulates innovation for students, ICT is one of the learning media that is commonly used in various fields of education because it can improve the quality and effectiveness of learning activities.
\end{abstract}

Keywords: Information and Communication Technology, Media, Education

\section{INTRODUCTION}

As time passes, education will continue to evolve as time passes. Education is also one of the key pillars of a society in which the quality of a country can be seen from the quality of its education. Education is the most significant predictor for the growth of a nation [1]. The mastery of ICT (Information and Communication Technology) is now very important in the digital age of 4.0. The primary need is to use computers/laptops to view, process and present information, both individually and in groups.

ICT has become a requirement in daily life in the new digital age of 4.0. ICT is the product of human engineering, which works to store, manipulate and transmit information in the form of messages, ideas or ideas from one group to another, so that the transmission of information is quicker and more widely spread [2].

The rapid advancement of technology in the modern age makes it possible for us to experience ICT in daily life. It is therefore very necessary to incorporate ICT in the field of education. In the 21 st century learning process, teachers aspire to be able to use ICT as a learning tool, teachers need to be able to operate and handle typewriters as a medium and learning resource. Teachers must use it interchangeably with teachers of other grade levels [3]. Teachers need a revolution in learning technologies, such as e-learning, to improve the quality and efficacy of the teaching and learning process in schools [4]. With the presence of ICT (Information and Communication Technologies) providing obstacles in the field of education, students are more interested in studying ICT than other learning materials, and students are even able to spend hours on computers to access the Internet and search for information that cannot be accessed at school. This kind of phenomenon is a huge challenge and a homework for the field of education to be able to take on and make learning innovations. Do not allow the field of formal education to be used solely as a place to receive a diploma without contributing to the next generation of the nation's struggle to become future leaders.

This is the challenge of 21 st century learning, where the presence of ICT in the field of education requires students to be imaginative, inventive, analytical and metacognitive, and to allow students to collaborate and work collaboratively (in groups) in the expectation that the information and skills they have gained will be used as provisions. Exist in a culture that has both a local and a global character that can be accounted for both personally and socially. Ramdhani \& Wulan [5] argues that ICT in education opens up new horizons for opening up access and shifting learning habits. 
The growth of ICT (Information and Communication Technology) is so rapid that if we do not keep up with technological advances, we will be far behind. Like it or not, we must all be interested in the advancement of the mastery of science and technology.

As we know, ICT (Information and Communication Technology) in English is a very rapid development. Almost everyone has used items related to ICT creation, such as cellphones, the internet, tablets that are widely used in everyday life. In addition to the world of education, ICT production is also required in the field of learning activities.

In reality, in both formal and non-formal educational institutions, ICT involves computers, laptops, wireless networks, printers, scanners, video/DVD players, digital cameras, tapes/CDs, interactive whiteboards /smartboards. In this case, it should be emphasized that the function of ICT is to serve as an enabler or mechanism that enables the process of education and learning to take place.

If the learning process is formalized in schools, it is intended to guide changes in students in a planned manner, both in terms of awareness, skills and attitudes. The exponential growth of science and technology is gradually promoting attempts to reform the use of technical findings in learning activities. All teachers are expected to be able to make use of what can be offered by the school and not to rule out the possibility that these resources are consistent with the innovations and demands of the times.

In order to achieve educational goals in general and learning objectives in schools in particular, learning media using ICT is therefore indispensable for learning activities. Means [6] states in their research report that the need for school populations to use learning technology is part of the learning change. The need for technology to be used was initially motivated by evidence that existed in non-school communities (business, government, and the general public) that frequently used technology in communication, information and business activities. The reality becomes a burden on the school community to use technology as well, so that students are familiar with technology. In subsequent developments, due to the effects of advances in the implementation of increasingly advanced technology, technology has become a platform and method that is considered to be very critical and strategic to promote the achievement of learning reform objectives.

Study on the use of ICT as a learning medium has been carried out by several scholars in the field of education. On the basis of the findings of Kristiawan [7] study, computer-assisted instruction as an additional instruction method for successful teaching involves providing teachers with professional development and success. Implement ICT in the field of education.

ICT (Information and Communication Technology) covers two elements, namely information technology and communication technology. Information technology involves everything related to the operation, the use of a tool, the manipulation and the management of information. Communication technology encompasses anything related to the use of software to process and transfer data from one computer to another. ICT mastery therefore means the ability to understand and use ICT resources in general, including computers (computer literate) and to understand knowledge (information literate).

ICT is a series of tools used to communicate and produce, disseminate, store and maintain information. The technology referred to includes computers, the internet, broadcasting technology (radio and television) and telephony. UNESCO [8] defines ICT as a technology used to communicate, develop, manage and distribute information. The general definition of ICT is machine, internet, telephone, TV, radio and audiovisual equipment. Bambang Warsita [9] argues that information technology is a means and infrastructure (hardware, software, useware) of systems and methods for receiving, transmitting, processing, reading, storing, organizing and making practical use of data.

According to Abdulhak [10], the advantages of technology and information are divided into three forms of use of ICT, namely: a). ICT as a tool (aid) for education, namely as a complement to the definitions presented; b) ICT as a source, namely as a source of knowledge and information search; c) ICT as a learning system. In this case, in line with the opinion of Reeves [11], for the purpose of learning in schools, there are two key approaches to the use of technology, namely that students should learn 'from' and 'with' technology. Learning from technology is practiced using computerbased training (tutorials) or integrated learning systems. Learning 'with' technology uses technology as cognitive instruments and uses technology in constructivist learning environments.

In a method that will be used, of course, there are many benefits from the system that will be used and created, including the benefits of using ICT-based learning media in education, namely: (a) abstract content (outside of daily experience); (b) hypertext power (compared to books); (c) reshaping learning objects and student thinking; (d) enhancing student retention/memory through learning; (e) to overcome the limitations of space, time and energy; (f) to allow students to learn independently on the basis of their abilities, visual, auditory and kinesthetic skills; (g) to provide the same stimuli, to equalize experiences and to establish the same perception; (h) learning is more interesting; I learning time can be shortened; (j) the 
learning process can take place at any time and wherever appropriate.

The media comes from the Latin medium, which means intermediate, middle or introductory. Gerlach and Ely [12] argue that when interpreted in broad terms, the media is a person, material, or event that creates conditions that allow students to acquire knowledge, skills, or attitudes. In this situation, the media are the teachers, the textbooks and the school setting.

Sukiman in Sari [13] also claims that the media is capable of sending and transmitting messages to recipients in order to stimulate students in the learning process. The use of learning media must be able to stimulate student curiosity and enthusiasm so that students are willing to engage in learning from start to finish. Learning media must also be able to inspire students to be involved in their learning activities. Students will undergo a positive and enjoyable learning process. In this case, the right approach is required to make learning interesting for students, including learning using ICT-based learning media. Gerlach and Ely [12] set out three characteristics of the media which indicate why the media are used and what the media can do, which teachers might not be able to do, including; a) fixative characteristics; b) manipulative characteristics; c) distributive characteristics.

Hamalik [14] argues that the use of educational media in the teaching and learning process can create new desires and interests, inspire and stimulate learning behaviors, and have a psychological effect on students.

Sudjana and Rivai [15] argue that the advantages of learning media in student learning practices, i.e. a) would draw more exposure to students in order to promote enthusiasm for learning; (b) the context of the learning material will be clearer so that it can be better understood by students; (c) teaching strategies will be more diverse, not just verbal contact in the teacher's speech; (d) students will do more learning activities because they not only listen to the teacher's explanation but also to other activities such as listening, performing, explaining, acting and others.

On the basis of technological advances, learning media can be divided into four types: (a) print media; (b) audio technology media; (c) computer technology media; and (d) rapid technology and computer media. In terms of facilities, SD Negeri Berkat has facilitated learning by using ICT as a learning medium, but there are still some teachers who have not mastered ICT so that they are unable to use ICT as a medium for learning activities. Based on the history and research findings of previous researchers, the researchers are interested in analyzing and evaluating the benefits of ICT-based learning media in SD Negeri Berkat.

\section{METHODS}

This research is a research project. Methodology is a determining factor for the merits of writing scientific papers [16]. According to Sugiyono [17] qualitative research methods are research methods focused on the theory of positivism used to investigate the conditions of natural objects (in comparison to experiments) where the researcher is a main instrument, sampling of data sources is done on purpose where the researcher decides the requirements for which respondents can be chosen as samples. The description of the purpose according to Sugiyono [17] is a sampling technique with certain considerations. Purpose sampling is a non-probability sampling, which means that it does not have equal opportunities for each population.

The goal of this research is the teachers of SDN Berkat OKI District who use ICT as a learning medium. Data collected by observation and interviews. Researchers conducted direct interviews with teachers and school principals in order to obtain reliable information.

\section{RESULTS AND DISCUSSION}

Almost everyone has used items related to ICT creation, such as cellphones, the internet, tablets that are widely used in everyday life. ICT is also required in the development of learning experiences in the world of education.

Hamalik [14] argues that the use of educational media in the teaching and learning process can create new desires and interests, inspire and stimulate learning behaviors, and have a psychological effect on students.

Arsyad [19] argues that the functional benefits of learning media in learning practices include: a) learning media can explain the presentation of messages and knowledge in order to speed up and enhance learning processes and outcomes; b) learning media can increase and guide students' attention so that it can contribute to motivational learning; more direct contact between students; and the use of ICT in learning typically uses hardware and software along with supporting applications, such as computing devices connected to the Internet, $\mathrm{LCD} /$ projectors, learning CDs, television, or the use of certain websites on the Internet.

In ICT-based learning, support for internet-based connections is also indispensable, apart from software support. This encourages students and teachers to take part in distance learning programs, not necessarily face to face. However, this can be accomplished remotely, linked to an internet network. With this internet network, a person can access different data through browsing to different data providers (servers) in different parts of the world. 
In reality, in both formal and non-formal educational institutions, ICT involves computers, laptops, wireless networks, printers, scanners, video/DVD players, digital cameras, tapes/CDs, interactive whiteboards /smartboards. In this case, it should be emphasized that the function of ICT is to serve as an enabler or mechanism that enables the process of education and learning to take place. The teacher describes the lesson using a laptop projected via an LCD/projector.

On average, the outcomes of interviews conducted by researchers with classroom teachers at SD Negeri Berkat have demonstrated very good benefits from the use of ICT as a learning medium. They feel very effective in growing student awareness and making students more motivated and enthusiastic about engaging in learning activities.

The learning media used are written in the form of pictures of the teacher, then put on the blackboard used in the learning process.

Based on the findings of observations and interviews with homeroom teachers at SD Negeri Berkat, ICTbased learning media have significantly assisted students in the learning process. Students use the Internet as a method to find answers to the questions posed by the instructor. The teacher also uses images and learning videos as media that are projected on the $\mathrm{LCD}$ /projector so that students can quickly absorb and understand lessons. Students can also sometimes find answers to questions via the Internet if there are questions or questions from the teacher that are not in the textbook. The school principal also offers quota assistance to teachers in order to ensure a more successful teaching and learning process.

\section{CONCLUSION}

This study has culminated in the use of ICT as a learning medium in SD Negeri as a result of its ability to promote learning practices. Teachers and students learn in a friendly, meaningful, imaginative and inventive manner. The growth of ICT is so rapid and inevitable that if we do not keep up with technological advances, we will be far behind. It is also imperative that we engage in the progress of the mastery of science and technology. Based on the findings of the research conducted at SDN Berkat, on average, teachers really felt the advantages of using ICT as a learning tool. They are very helpful in improving student motivation and awareness. It can therefore be seen that learning using ICT at SDN Berkat is considered to have a very strong effect and is well used by all school participants to achieve general learning goals along with the times.

\section{ACKNOWLEDGMENTS}

The author would like to thank Dr. H. Bukman Lian, M.M., M.Si., Chancellor of the PGRI Palembang
University, Dr. Syaiful Eddy, M.Sc., Director of the Postgraduate Program at the PGRI Palembang University, Dr. Happy Fitria, M.Pd., Head of Education Management Study Program and all those who have helped morally and materially. May the goodness become multiple good deed.

\section{REFERENCES}

[1] Asvio, N., Yamin, M., \& Risnita. (2019). Influence of Leadership Style, Emotional Intelligence and Job Satisfaction toward Organizational Commitment (Survey at SMA Muhammadiyah South Sumatera). International Journal of Scientific \& Technology Research 8 (8).

[2] Affandi, M. (2017). Teknologi Informasi \& Komunikasi dalam Pendidikan [Information \& Communication Technology in Education]. Kuningan: YNWH (Yayasan Nurul Huda Windusengkahan).

[3] Primasari, D. A. G., Kristiawan, M., \& Fitria, H. (2020). Developing Instructional Media of Curriculum 2013 Based on Information and Communication Technology. Education Journal 3(2), 24-34. http://www.itspoa.com/?thread-1089111.html

[4] Rahmadoni, J., Arifnur, A. A., \& Wahyuni, U. M. (2020). Penerapan Schoology Sebagai Learning Management System Bagi Guru SMAN 1 Sutera [Implementation of Schoology as a Learning Management System for Teachers of SMAN 1 Sutera]. Jurnal Hilirisasi IPTEKS volume 3 No 2.

[5] Ramdhani, M.A.; Wulan E.R. The Analysis of Determinat Factors in Software Design for Computer Assisted Intruction. International Journal of Scientific \& Technology Research, 2012, 1(8).

[6] Means, B. (1993). Using Technology to Support Education Reform. Amerika Serikat: US Government Printing Office.

[7] Kristiawan, M. (2014). A Model for Upgrading Teachers Competence on Operating Computer as Assistant of Instruction. Global Journal of HumanSocial Science Research.

[8] UNESCO. (2004). Schoolnettoolkit. Bangkok: UNESCO Asia and Pacific Regional Bureau for Education.

[9] Warsita, B. (2008). Teknologi Pembelajaran: Landasan \& Aplikasinya [Learning Technology: Foundation \& Applications]. Jakarta: Rineka. 
[10] Abdulhak, I. (2013). Teknologi Pendidikan [Education Technology]. Bandung: PT Remaja Rosdakarya

[11] Reeves, T.C. (1998). The impact of media and technology in schools. A research report prepared for the Bertelsmann Foundation. Amerika Serikat: University of Georgia.

[12] Gerlach, V.G Dan Ely, D.P. (1971). Teaching and Media. Englewood Cliffs: Prentice Hall, Inc.

[13] Sari, D. O. dkk. (2018). Pengembangan Media Moonstar (Monopoli Super Pintar) Pada Mata Pelajaran IPS Materi Perkembangan Teknologi Produksi, Komunikasi, Dan Transportasi Untuk Siswa Kelas IV Sekolah Dasar [Moonstar Media Development (Super Smart Monopoly) in Social Studies Subjects for the Development of Production, Communication and Transportation Technology for Class IV Elementary School Students]. Widya Wacana. (Vol. 13.No. 2). http://dx.doi.org/10.33061/ww.v13i2.2260

[14] Hamalik, O. (1986). Media Pendidikan [Educational Media]. Bandung: PT Citra Aditya Bakti.

[15] Sudjana, N., \& Rivai. (1992). Media Pengajaran [Teaching Media]. Bandung: Sinar Baru Algensindo.

[16] Muttaqin, K., \& Rahmadoni, J. (2020). Analysis and Design of File Security System AES (Advanced Encryption Standard) Cryptography Based. Journal of Applied Engineering and Technological Science (JAETS), 1(2), 113-123. https://doi.org/10.37385/jaets.v1i2.78

[17] Sugiyono. (2018). Metode Penelitian Pendidikan [Educational Research Methods]. Bandung: Alfabeta.

[18] Arsyad, A. (2007). Media Pembelajaran [Learning Media]. Jakarta: Raja Grafindo Persada. 